This item was submitted to Loughborough's Research Repository by the author.

Items in Figshare are protected by copyright, with all rights reserved, unless otherwise indicated.

\title{
The market liquidity timing skills of debt-oriented hedge funds
}

\section{PLEASE CITE THE PUBLISHED VERSION}

http://dx.doi.org/10.1111/eufm.12090

\section{PUBLISHER}

(c) Wiley

\section{VERSION}

AM (Accepted Manuscript)

\section{PUBLISHER STATEMENT}

This work is made available according to the conditions of the Creative Commons Attribution-NonCommercialNoDerivatives 4.0 International (CC BY-NC-ND 4.0) licence. Full details of this licence are available at: https://creativecommons.org/licenses/by-nc-nd/4.0/

\section{LICENCE}

CC BY-NC-ND 4.0

\section{REPOSITORY RECORD}

Li, Baibing, Ji Luo, and Kai-Hong Tee. 2016. "The Market Liquidity Timing Skills of Debt-oriented Hedge Funds”. Loughborough University. https://hdl.handle.net/2134/21220. 


\title{
The Market Liquidity Timing Skills of Debt-Oriented Hedge Funds
}

\author{
Baibing Li, Ji Luo and Kai-Hong Tee* \\ School of Business and Economics, Loughborough University \\ Loughborough LE11 3TU, UK
}

\begin{abstract}
We investigate the liquidity timing skills of debt-oriented hedge funds following the 2008 credit crisis, which demonstrated the importance of understanding liquidity conditions to manage the market exposure of investments. We base the analysis on the estimated comovements of fixed income and equity market liquidity. Our findings, which are statistically robust, show evidence of liquidity timing ability in the fixed income market for all debtoriented hedge fund strategy categories. Joint market liquidity timing skill, however, is only found in some categories. Our findings suggest that debt-oriented hedge fund managers use a sophisticated set of timing strategies in their investment managements.
\end{abstract}

Keywords: Fixed income market; hedge funds; liquidity timing skill; market exposure JEL classification: $G 1 ; G 11 ; G 23$

\footnotetext{
* Corresponding author. School of Business and Economics, Loughborough University, Loughborough, LE11 3TU, United Kingdom; tel. +44 1509 222156; fax: +441509 223960. E-mail addresses: B.Li2@lboro.ac.uk (Baibing Li); J.Luo2@lboro.ac.uk (Ji Luo); K.tee@lboro.ac.uk (Kai-Hong Tee).

* The authors thank Professor Robert Watson, the two anonymous referees, and the editor Professor John Doukas for their constructive comments, which helped improve the manuscript.
} 


\section{Introduction}

This paper investigates the ability of hedge fund managers to time market liquidity. Specifically, we test whether debt-oriented hedge fund managers adjust market exposure when appreciable changes in market liquidity conditions are anticipated. We focus on liquidity timing for two main reasons. First, there is a clear connection between market-wide liquidity and fund performance. For example, during the 2008 financial crisis, many funds experienced large negative returns since they had to contend with a massive market-wide liquidity squeeze, above normal investor withdrawals, and a simultaneous and persistent stock market collapse. Fund managers could potentially avoid such liquidity-induced losses if they had the ability to reliably predict future market liquidity conditions and adapt their portfolio exposure accordingly. Second, it is clear that hedge funds have great flexibility regarding their choices of investment classes and strategies. Indeed, one of the attractions of hedge funds is precisely the ability to adopt dynamic investment strategies that lead to timevarying market exposure (Fung and Hsieh, 1997, 2001; Patton and Ramadorai, 2013). Kessler and Scherer (2011) confirm that hedge funds routinely use a wide variety of financial vehicles and investment strategies specifically tailored to different markets. Nevertheless, irrespective of the asset class, since the highest returns tend to be associated with the highest risk exposures, it is inevitable that many hedge funds adopt strategies associated with investing in (under-valued) assets with low liquidity levels. Obviously, in the absence of a significant degree of market liquidity timing ability, the long-term sustainability of such funds would be highly questionable. Such funds would be entirely unhedged with respect to the major source of risk essential to their investment strategy. Hence, liquidity crises would be a little more than a risky bet that investors would have sufficient above-average returns over an extended period to survive the relatively rare but unavoidable occasions when market 
liquidity conditions reverse and induce a potentially fatal negative outcome (Kessler and Scherer, 2011).

The literature on the timing ability of fund managers has traditionally focused on managers' ability to time market returns and/or volatility. The pioneering market timing model is based on the market return timing model of Treynor and Mazuy (1966), while Busse (1999) documents that fund managers demonstrate the ability to time market volatility by increasing (reducing) portfolio exposure when the market is less (more) volatile and Chen and Liang (2007) develop two models to investigate the joint timing ability of market returns and market volatility. Using the quadratic model of Treynor and Mazuy (1966) and taking into account the estimated costs associated with liquidity constraints, French and Ko (2007) examine whether long-short equity hedge funds exhibit market timing skill. Park (2010) further develops the ideas of these above two papers by dividing hedge fund excess returns into three components: factor timing, asset selection, and the risk premium. However, none of the above three papers find evidence that hedge funds have any meaningful market timing skills.

In contrast, Chen and Liang (2007) report finding that hedge fund managers are able to time market returns and volatility. They also report that hedge funds appear to have the ability to jointly time the first two moments of the return distribution. Cao et al. (2013) produce evidence that equity-oriented hedge fund managers are able to time equity market liquidity. These findings are consistent with those of Chincarini and Nakao (2011), who find some equity hedge funds have the ability to time the market based on Fama-French size and value factors. Also relevant to the present study are the results of Chincarini (2014), that 
quantitative hedge funds, including equity-oriented hedge funds, are significantly better market timers than qualitative funds, making them better overall performers.

Our paper focuses on the liquidity timing skills of debt-oriented hedge funds, an area that has not been previously empirically investigated. The importance of bond market liquidity cannot be over-estimated, especially during periods of financial crisis, such as during the default of Russian GKO government bonds in August 1998, an episode that, according to Khandani and Lo (2011), widened credit spreads, lowered liquidity, and induced extreme losses upon fixed income arbitrage hedge funds, the best known casualty being Long Term Capital Management. Indeed, Long Term Capital Management still comprises the seminal case study regarding the importance of anticipating changes in bond market liquidity and of the necessity of hedge funds to adjust portfolios in anticipation of future liquidity conditions.

We investigate to what extent (if any) debt-oriented hedge fund managers have the ability to time fixed income market liquidity by strategically adjusting the underlying fixed income market exposure based on their forecasts of the market liquidity conditions ${ }^{1}$ In addition, we note that the bond and equity markets are the two markets most commonly transacted in by the hedge funds. Moreover, the ability to invest with fewer restrictions than mutual funds also allows hedge funds to take positions in sophisticated strategies leading to more refined market timing. Therefore, we hypothesize and test that debt-oriented hedge

\footnotetext{
${ }^{1}$ Other factors have also been analysed on the effects of hedge fund risk and returns in the literature. Sadka (2010) demonstrates that liquidity risk is an important factor in the cross section of hedge fund returns, while Billio et al. (2009) study the effects of financial crises on hedge fund risk and show that liquidity, credit, the equity market, and volatility are common factors. Bali et al. (2011), however, extend the application to include macroeconomic risk factors, such as the US Consumer Price Index, the monthly growth rate of industrial production, and the monthly percent change in US non-farm payrolls.
} 
funds exploit the co-movements of debt and equity market liquidity as information inputs to time the fixed income market liquidity.

Chordia et al. (2005) study the co-movement of debt and equity market liquidity. They also investigate the liquidity dynamics across the two markets and they find significant correlation between their liquidities, implying possible common driving factors. The authors explain that the implementation of expansionary monetary policies is one such factor, especially in times of crisis. Further findings by Golyenko and Ukhov (2009) reveal that changes in the liquidity of the bond and equity markets are lead-lag related. In essence, the impact of liquidity changes in the equity market then impacts the liquidity of the bond market in a manner which suggestive of a cascade towards increasingly liquid assets (or a flight-toquality). These findings are consistent with the evidence of Chordia et al. (2005) on the relation and co-movement of liquidity between the equity and bond markets.

A distinguishing feature of this paper is that we investigate if debt-oriented hedge funds exploit the co-movements of debt and equity market liquidity as inputs to time fixed income market liquidity. We assume that debt-oriented hedge fund managers observe the comovement of liquidities in these two markets, especially when overall market liquidity conditions change. We further assumed that fund managers then use this information to assist in adjusting the underlying portfolios' exposure in their focus markets ${ }^{2}$. To investigate if debt-oriented hedge funds exploit the co-movements of debt and equity market liquidity, we

\footnotetext{
${ }^{2}$ Chen (2007) provides evidence that hedge fund managers could transact in several markets and shows that, for example, the event-driven Hedge funds category has statistically significant loadings on US stock, non-US government bonds and high-yield bond markets, with the latter having the largest loading. On that basis, Chen defines these markets as the focus markets for event-driven Hedge funds. This implies the likelihood of hedge fund managers trading in more than one market underlying their classified strategies.
} 
first extend the commonly used theoretical model for market timing and then empirically test the debt-oriented hedge fund managers' joint timing ability regarding fixed income market liquidity and equity market liquidity. Our findings, which are robust to data bias, reveal evidence of debt-oriented hedge fund managers exhibiting joint liquidity timing in the fixed income focus market at both strategy category and individual fund levels.

This paper is structured as follows. Section 2 briefly describes the market data and the liquidity measures used. Section 3 presents the main empirical results. Section 4 conducts further robustness tests and investigates liquidity timing ability using the bootstrap approach. Section 5 concludes the paper.

\section{Data}

In this section, we briefly explain the hedge fund data used in the analysis. We also discuss the liquidity measures in the fixed income and equity markets.

\subsection{Hedge funds}

We gather our data on debt-oriented hedge funds from Morningstar, ${ }^{3}$ which classifies hedge funds into six broad strategic categories: directional equity, directional debt, event, global derivatives, multi-strategy, and relative value, each of which further includes several sub-categories. In this paper, we focus on all debt-oriented hedge funds which include the

\footnotetext{
${ }^{3}$ Other data vendors are commonly used in the academic research on hedge funds, such as TASS and HFR. Each differs in terms of the number of funds available and the extent of survivorship bias, which is addressed in Section 3.2. Our empirical findings, based on data from Morningstar, are also further bootstrapped for validation purposes (see Section 4.2). It is beyond the scope of this paper to investigate and discuss the differences among these various hedge fund databases. However, interested readers are referred Joenväärä et al. (2013) for more details.
} 
following four sub-categories: long-only debt, long/short debt, debt arbitrage, and fund of fund $\operatorname{debt}^{4}$.

The hedge fund returns in this paper are examined using the seven-factor model proposed by Fung and Hsieh (2004) ${ }^{5}$. Table 1 provides descriptive statistics for the data used in the analysis. Panel A shows the average monthly returns on the debt-oriented hedge funds. These funds report returns net-of-fee on a monthly basis and have average assets under management of at least \$10 million following the literature (e.g., Chen, 2007; Aggarwal and Jorion, 2010; Stefanova and Siegmann, 2012; and Cao et al. 2013). We require each fund to have at least 24 monthly returns to obtain meaningful results ${ }^{6}$, following for example, Eling and Faust (2010) and Stefanova and Siegmann (2012). Panel B displays the factor data in

\footnotetext{
${ }^{4}$ According to Morningstar (2014), funds in the long/short debt and long-only debt categories study broad changes and prices in fixed income products. In many cases, the manager will select various fixed income products such as high-yield or emerging market debt to provide a fixed investment stream. Many debt funds leverage their returns to provide larger returns. Unlike debt arbitrage funds, these types of funds tend to have a net long market exposure (Morningstar, 2014). In particular, the long/short debt category includes funds that primarily adopt directional positions in global debt. Long and short positions are typically independent of each other. The majority of the funds' assets are invested in debt investments, but the fund manager can also include other instruments, such as emerging market debt, US debt, and global debt, along with credit default swaps. The long-only debt category includes long-only debt strategies in performing debt instruments. The strategies include mezzanine financing, private debt, high-yield debt, leveraged debt strategies, and other specialty finance funds. The debt arbitrage category includes funds that seek out pricing discrepancies between various private and public fixed income instruments, usually looking for global opportunities. Portfolio managers in this category primarily invest in fixed income derivative instruments. The fund of fund debt category includes debt funds that have statistically significant betas for at least one debt index or for a credit or duration spread. These funds primarily (50\% or greater) derive their directionality from debt-related hedge fund strategies. Debt funds can diversify geographically or can concentrate in a particular region. These funds can invest in strategies other than directional debt strategies, but the systematic risk is dominated by correlations to fixed income investments. See Morningstar (2014) for detailed information.
}

${ }^{5}$ The seven factors include both linear and option-like factors, and have been shown to explain variation in hedge fund returns well. Specifically, these factors include an equity market factor, a size factor, changes in the constant maturity yield on 10-year Treasury bonds, change in the spread between Moody's Baa and 10-year Treasury bonds, and three trendfollowing factors for bonds, currency, and commodities. These are available from http://faculty.fuqua.duke.edu/ dah7/HFRFData.htm and we thank the providers for these data.

${ }^{6}$ The arguments about sufficient history (as a sampling requirement) that a fund must have before it can lead to bias are mixed. In the literature, the duration for the sampling requirement varies. For example, Fung and Hsieh (1997) require 36 months of return history before including a fund in their empirical study, whereas Ackermann, et al. (1999) require funds to have 24 months of return history for inclusion in their tests. There is evidence that this bias, if it exists, is very small (Fung and Hsieh, 2000). Other forms of data bias are discussed in Section 3.2. 
Fung and Hsieh's seven-factor model. All the data used for analysis are from March 2005 to December 2012.

\section{[Table 1]}

\section{2. $\quad$ Liquidity measures}

The fixed income market liquidity measures we use are primarily based on the work of Longstaff et al. (2005), who first suggested that the variable for measuring the liquidity premium ought to be the corporate bond spread, that is, the difference between the par yields on a fixed-rate corporate bond and a corresponding fixed-rate government bond with matching maturities. On maturity, the spread reflects only two components: a default component and another residual component that Longstaff et al. (2005) interpret as reflecting a liquidity premium ${ }^{7}$. Gintschel and Wiehenkamp (2009) show that a simple liquidity factor based on the difference between corporate bond spreads and CDS is significantly associated with returns in a wide range of fixed income markets. They also find that the corresponding liquidity premium is time varying but persistent and drives serial and cross-sectional variations in fixed income prices.

We follow the method adopted by Kessler and Scherer (2011), whose approach was itself based on Longstaff, et al (2005), to construct the fixed income market liquidity measure. To do so, we use corporate bond, Treasury securities (as the risk-free asset), and CDX credit spread data. The corporate bond and Treasury securities datasets are obtained from

\footnotetext{
${ }^{7}$ Gintschel and Wiehenkamp (2009) explain that for bond issuers, active markets exist for credit default swaps (CDSs), which are insurance (protection) against the default of a particular reference bond of that issuer. The CDS insures the holder against loss due to the default of a particular reference bond and acts as a good proxy for the risk premium for the default risk. Strictly speaking, the CDS spread is not affected by liquidity concerns and can be used for a bond portfolio as a default risk proxy, while the difference between the bonds and CDS spreads on the same portfolio can be used for the liquidity factor proxy.
} 
Datastream, whereas the CDX credit spreads data are obtained from Thomson Reuters Eikon. For the corporate bond data, we use the BBB rated BofA Merrill Lynch US Corporate bond for five to 10 years, seven to 10 years and 10 to 15 years. For the risk-free asset, we use Treasury securities of five years and 10 years of maturity, respectively. The CDX credit spreads data are for five-years and 10-years. This results in three fixed income market liquidity measures: LFI10-15Y, LFI7-10Y, and LFI5-10Y .

For equity market liquidity measures, we use the liquidity measure developed by Pástor and Stambaugh (2003) ${ }^{9}$ to assess the equity-market liquidity timing ability of hedge fund managers. Panel $\mathrm{C}$ of Table 1 summarizes the liquidity measures used in this paper, that is, the Pástor-Stambaugh equity market liquidity measure and the three fixed income market liquidity measures calculated in this paper.

Table 2 reports the correlation coefficients of the three fixed income market liquidity measures and the equity market liquidity measure, which are between 0.35 and 0.41 , indicating these two markets are related and consistent with the literature on their comovement (Chordia et al., 2005; Golyenko and Ukhov, 2009). Our paper assumes debtoriented hedge fund managers use information on the correlations of liquidities in the two markets when they forecast the beta of their focus market (the fixed income market in this paper); this is investigated in the next section.

\footnotetext{
${ }^{8}$ These are calculated based on the difference between the excess rate of the BBB rated BofA Merrill Lynch US Corporate bonds for 10 - 15 years and the 10-year CDX credit spread (LFI10-15Y), the difference between the excess rate of the BBB rated BofA Merrill Lynch US Corporate bond for seven to 10 years and the 10-year CDX credit spread (LFI7-10Y)—where, due to availability of the seven-year CDX credit spread data, the 10-year CDX data are used instead----and the difference between the BBB rated BofA Merrill Lynch US Corporate bonds for five to 10 years and the five-year CDX credit spread (LFI5-10Y).

${ }^{9}$ These data are accessible at http://faculty.chicagobooth.edu/lubos.pastor/research.
} 
[Table 2]

\section{Empirical analysis}

In this section, we examine whether debt-oriented hedge fund managers are able to jointly time market liquidity by combining the bond and equity markets at both the aggregate strategy and individual fund levels. We also include the analysis for the period around the 2008 credit crisis and examine the impact of data bias.

\section{1. $\quad$ Tests of joint market liquidity timing}

The joint market liquidity timing (JMLT) model used in this paper is developed from Shanken (1990), who models the market beta $\bar{\nabla}_{0^{\circ}, O^{O}}$ of a focus market $M$ in time period $\alpha_{z}$ as a linear function of a fund manager's expected market conditions, that is. $\nabla_{0^{0}, O}=\nabla_{0^{0}}+$ इ' (ड़ उ अर्भद्रा information set available to the fund manager in period $_{z}$, and $\Xi$ is the timing coefficient. Following this general approach, Cao et al. (2013) focus on the equity market and consider an important market condition, the liquidity condition of the equity market, to test whether equity-oriented hedge fund managers have significant liquidity timing ability, that is,

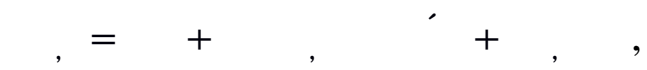

where $\nabla_{\ddot{i n}}$ is the fund's average beta in the equity market. The expression in parentheses represents the manager forecast (i.e. timing signal) using equity market liquidity, with $\ddot{i}, \mathrm{O}_{*} \boldsymbol{r}$ the measure of equity market liquidity in month $_{z}+1$. Since it is unrealistic for a timer to

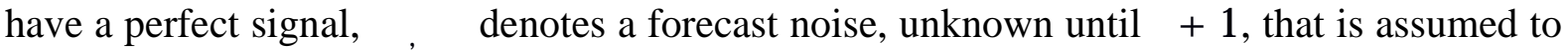
be independent with a zero mean. Note that following the market timing literature (e.g.

Ferson and Schadt, 1996; Busse, 1999), the manager's signal is de-meaned by subtracting。 ${ }^{\prime}$ T⿱宀 
for ease of interpretation. Cao et al. (2013) adopt the aggregate equity market liquidity measure developed by Pastor and Stambaugh (2003) in their model (1). Liquid markets are generally viewed as accommodating large quantities of transactions in a short time with little impact on asset prices. The Pastor-Stambaugh measure captures equity market liquidity associated with temporary price fluctuations induced by order flow, which can be interpreted as volume-related price reversals attributable to liquidity effects.

The seven-factor model proposed by Fung and Hsieh (1997, 2004) includes both linear and option-like factors and has been shown to explain variations in hedge fund returns. To control for fund exposures to other relevant factors when estimating the liquidity timing ability of hedge funds in the equity market, Cao et al. (2013) expand model (1) and use the seven-factor model as the main benchmark model as follows:

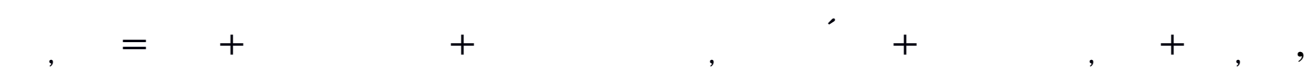

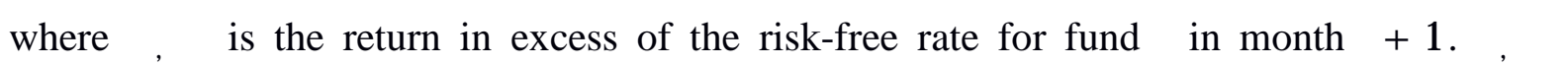
( $f=6$ in this case) denotes all the factors $a_{m_{z}}+1$ other than the equity market factor ' $\dagger_{\mathrm{O} \cdot \eta_{\mathrm{r}}}$ in the seven-factor model and the coefficient $\Xi$ measures liquidity timing ability. A positive timing coefficient $\Xi$ is expected since this indicates that the fund has a high (low) beta during good (poor) equity-market liquidity conditions. Cao et al. (2013) explain that this also indicates that the hedge fund manager has liquidity timing skills by increasing (decreasing) the hedge fund's exposure to the equity market prior to the rise (fall) of equity market liquidity. 
In this paper, we hypothesize that a debt-oriented hedge fund manager focuses on the fixed income market and forecasts the fixed income market beta using information on both equity market and fixed income-market liquidities as follows:

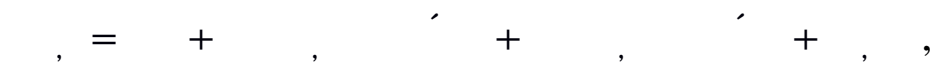

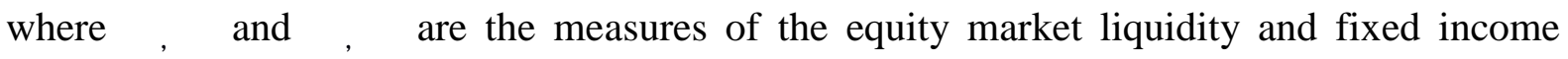
market liquidity in month $h_{\xi}+1$, respectively, and $\psi_{\Omega, Q_{n} \cdot r}$ denotes forecast noise unknown until $h_{z}+1$ that is assumed to be independent, with a zero mean. The manager's signal is de-

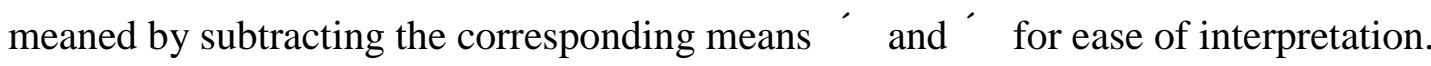

We substitute Eq. (3) into Fung and Hsieh’s (2004) seven-factor model to control the exposure of hedge funds' returns to the other factors and we include the forecast noise $\boldsymbol{H}_{\Omega, \mathrm{a}^{2} \boldsymbol{r}}$ within the error term, yielding the following JMLT model:

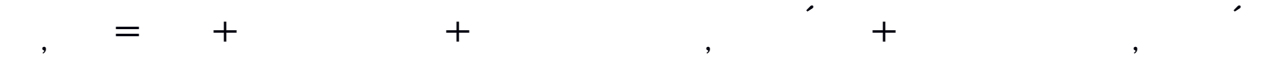

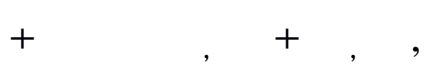

where षू $†$ stands for the bond market factor and ${ }_{\text {Hon }{ }_{r}}(f=6$ in this case) denotes the factors at $\mathrm{t}_{\mathrm{z}}+1$ other than the bond market factor in the seven-factor model. We wish to test the joint liquidity timing ability for the fixed income focus market based on the JMLT model

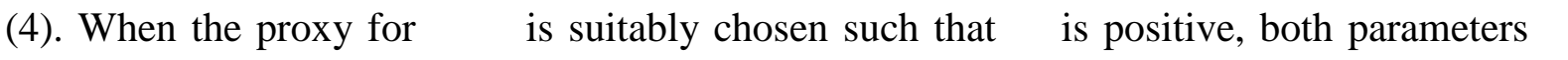
and $\mathbf{3}$ are expected to be significant and positive if the fund manager has joint timing skill: these take into account the fixed income market liquidity and equity market liquidity when forecasting the fund's beta. As explained earlier, a positive value of $\bar{\Sigma}$ indicates that the hedge fund manager has liquidity timing skills underlying the hedge fund's exposure in the fixed income market. This skill is further used when hedge fund managers also consider joint liquidity with the equity market, as implied by उ. A positive value of उ is also expected since 
this indicates the presence of liquidity timing skills when fund managers increase (decrease) exposure to fixed income market prior to the rise (fall) of the joint liquidity of the bond and equity markets ${ }^{10}$.

We first discuss our findings, which is based on the JMLT model (4) at the aggregate strategy level, by providing a general overview of the liquidity timing ability of debt-oriented hedge funds. To do so, we pool three of the debt-oriented strategy categories - that is, longonly debt, long/short debt, and debt arbitrage (fund of fund debt is not included to avoid potential double counting) — to investigate the average joint liquidity timing ability across these three categories. The results, as reported in the second column of Table 3 in Panel A, where the fixed income market liquidity is measured by LFI10-15Y, show that, after controlling the seven factors ${ }^{11}$, the two timing coefficients !! and ${ }^{-}$are positive and significant. This implies debt-oriented hedge fund managers use information on both equity market and fixed income market liquidities to forecast the fixed income market beta to adjust exposure in the fixed income focus market. We repeat the analysis with two other liquidity measures, LFI5-10Y and LFI7-10Y, to check for robustness. The results in Panels B and C of Table 3 are consistent with those shown in Panel A since they indicate that the joint market liquidity timing ability is not dependent on the choice of the liquidity measure in the fixed income market.

\section{[Table 3]}

\footnotetext{
${ }^{10}$ To ensure $\nabla_{i q}$ is positive (Fung and Hsieh, 2004), throughout this paper, the proxy for षू $†$ is chosen to be a 'negative monthly change' in the 10-year Treasury constant maturity yield.

${ }^{11}$ Fung and Hsieh (2001) consider an eight-factor model in which an emerging market index factor is added to the sevenfactor model. We also substituted Eq. (3) into the eight-factor model to test the joint liquidity timing ability. The empirical results (available upon request) are consistent with those shown in Table 3.
} 
We next consider each of the three individual debt-oriented hedge fund strategy categories separately, as well as the fund of fund debt strategy. The results of the analysis are reported in columns 3 to 6 of Panel A in Table 3. From Table 3, we observe some differences in the findings as compared to debt-oriented hedge funds in general. Controlling for the seven factors, we find the two timing coefficients $\bar{\Sigma}$ and 3 are significantly positive at the $5 \%$ level for the long-only debt and fund of fund debt strategy categories. This result provides evidence consistent with the contention that hedge fund managers use information on both equity market and fixed income market liquidities to forecast their fixed income market beta and adjust their exposure in the fixed income focus market accordingly. According to Eq. (3), this shows the beta of these funds is positively correlated with both fixed income market liquidity and equity market liquidity conditions. This suggests successful joint liquidity timing where the funds have relatively high (or low) fixed income market exposure in the anticipation that the aggregate financial market liquidity conditions are good (or poor). Findings from the long/short debt and debt arbitrage hedge funds, however, shows that the managers only use fixed income market liquidity to adjust their forecast for the beta (significant at the 5\% level in Panel A), and not joint market liquidity. We again repeat the analysis with two other liquidity measures, that is, LFI5-10Y and LFI7-10Y, to check for robustness. The results in Panels B and C of Table 3 are consistent with those of Panel A in terms of bond market liquidity and joint market liquidity timing abilities, indicating that they are not dependent on the choice of liquidity measures in the fixed income market ${ }^{12}$.

\footnotetext{
${ }^{12}$ As part of the robustness check, we have also investigated the scenario where the liquidity condition in the equity market

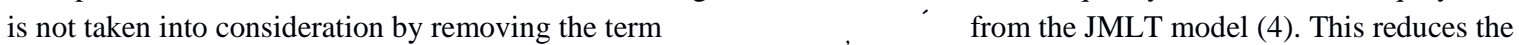
model to Eq. (2) of Cao et al. (2013). The findings of the regression analysis (not shown here but available upon request) reveal that the coefficient !! for timing the fixed-income-market liquidity is positive and significant. This implies that hedge fund managers in the fixed-income market have the ability to time the bond market's liquidity.
} 
Long-only debt hedge funds mainly focus on long positions in the fixed income market (about $75 \%$ is exposed to fixed income). In light of downside risk protection, a forecast that is based on the liquidity information from both the fixed income and equity markets is more effective than one that solely relies upon data from the fixed income market. We foresee that the investment of long-only debt hedge funds in the equity market could be one way for these funds to hedge or reduce risks since equity market investments also tend to use similar strategies, such as the buy-and-hold strategy. Such familiarities could help explain why long-only debt hedge fund managers could be drawn towards timing liquidity in both equity and fixed-income markets. In addition, fund of fund debt funds select debt-oriented hedge funds. Thus, the performance of these funds reflects the overall performance of the debt-oriented hedge fund sector, which as seen in Table 3, indicates a significant element of joint liquidity timing ability. The results relating to long/short debt and debt arbitrage hedge

funds reveal that managers have only fixed income market liquidity timing ability. This finding could be due to the nature of the strategies the managers typically adopt, which are generally more flexible and equally capable of being exploited to serve hedging or downside loss reduction. The result would be joint liquidity timing not necessarily being their main approach to reduce risks. Managers could resort to using alternative strategies, for example, volatility timing and/or return timing, which are further discussed in Section 4.

\subsection{Impact of data bias}

In this subsection, we briefly discuss the impact of the data bias, particularly survivorship and backfilling bias. This paper follows the literature to include both live and defunct funds in the analysis. Clearly, if funds exit the database mainly due to poor performance, the inclusion of defunct funds is necessary to mitigate this survivorship bias. 
The backfill bias ${ }^{13}$ arises because a hedge fund could backfill its historical performance when it is added into a database. To address this bias, we follow Avramov et al. (2011), Fung and Hsieh (2000, 2011), and Cao et al. (2013) by discarding hedge funds' first 12 months of returns considering backfill effects. The results are displayed in Table 4. It can be seen that, even after controlling for this, the analysis still provides results consistent with liquidity timing ability in the fixed income focus market. However, since the analysis requires all funds to have at least 24 monthly returns after their backfill periods, it tilts the sample towards funds with longer histories. This leads to excluding younger funds and funds with short histories from the analysis.

\subsection{Results for the period around the 2008 financial crisis}

Our full sample period, which covers from 2005 to 2012, includes the period of the 2008 financial crisis. To evaluate if awareness of the market liquidity crisis made an impact on liquidity timing ability, we further examine our findings by analysing the results from July 2007 to December 2012, where this is chosen as the period "after the financial crisis", following Ben-David et al. (2012).

Table 5 presents the results for the period after the financial crisis, which is consistent with the findings for the full period ${ }^{14}$ and reaffirms the liquidity timing skills of debt-oriented hedge funds. Liquidity in the bond market declined after the recent financial crisis following

\footnotetext{
${ }^{13}$ Other biases such as selection bias are difficult to examine because we do not observe funds that choose not to report to any database. Nevertheless, the literature (e.g. Fung and Hsieh, 1997; Agarwal, et al 2013) shows evidence that the selection bias could be limited.

${ }^{14}$ We also analyse the period before the recent financial crisis (prior to July 2007) as Ben-David, et al (2012) do. Our findings do not exhibit any significant liquidity timing ability for this period. The implication may not be conclusive given the short time period. The results could also be attributed to the far few observations used in the regression analysis in this period due to data availability. These results are not presented due to lack of space but are available upon request.
} 
the freezing of the money markets in August 2007 and the collapse of Lehman Brothers in September $2008^{15}$. Our findings reveal that the hedge funds managers were aware of this change in market liquidity conditions and took action to adjust their market exposure accordingly.

\section{[Table 5]}

\subsection{Joint liquidity timing at the individual fund level}

Our findings from previous subsections reveal evidence of liquidity timing ability at the aggregate strategy level for debt-oriented hedge funds. To further substantiate this finding, we now investigate if these debt-oriented hedge funds also acquire liquidity timing ability at the individual fund level.

To do this, we conduct analysis at the individual fund level by estimating the regression coefficients using the JMLT model (4) for each fund. The null hypotheses of $\bar{\Sigma}=0$ and $\bar{\Xi}=0$ are tested and the corresponding $t$-statistic calculated. Due to the large number of hedge funds included in each strategy, we only present the results using the distribution of $t$-statistics for cross-sectional individual hedge funds' liquidity timing coefficients in the fixed income market in Table 6.

\section{[Table 6]}

\footnotetext{
${ }^{15}$ See the industry report by, for example, Fidelity Investment (2014).
} 
The numbers in Panels A to C of Table 6 report the percentages of hedge funds with the $t$-statistics of the liquidity timing coefficient $\bar{\varepsilon}$ that exceed the indicated values. For example, $14 \%$ of the hedge funds in the long/short debt category, reported in Panel A, indicate that they have a $t$-statistic of the coefficient $\bar{\Sigma}$ greater than 1.960 . On the other hand, the numbers in Panels D to F of Table 6 report the percentages of hedge funds with t-statistics of the liquidity timing coefficient 3 that exceed the indicated values.

Overall, Table 6 shows that, for the liquidity timing coefficients $\bar{\Sigma}$ and 3 , a substantial portion of hedge funds in each strategy category are associated with a $t$-statistic greater than 1.28. This provides some evidence of joint market liquidity timing ability at the individual fund level. In particular, for long/short debt and debt arbitrage categories, we see some topranked funds exhibit joint market liquidity timing ability, although there is essentially no evidence of joint market liquidity timing ability averaged across the entire category (as shown in Table 3) ${ }^{16}$.

Table 6 also reports some hedge funds with $t$-statistic smaller than -1.28 , that is, these hedge funds show negative liquidity timing ability. This suggests that hedge fund managers adjust portfolios' market exposure in the direction opposite to hedge fund managers with successful liquidity timing skills (Cao et al., 2013). Generally, we can see that the right tails of the distributions of the $t$-statistics are much thicker than the left tails. Hence, many more funds exhibit successful positive timing ability than negative timing ability. This finding is

\footnotetext{
${ }^{16}$ It should also be noted that the data points used in each regression analysis at the individual fund level are much lower than those used at the aggregate strategy level. For example, we require each fund to have at least 24 monthly returns. Statistically, for some funds with only 24 data points in the analysis, we are less likely to obtain conclusive results. Nevertheless, empirical analysis still reveals some positive results
} 
consistent with studies undertaken with respect to the US equity market (e.g. Chen and Liang, 2007).

\section{Further analysis}

In this section, we extend our JMLT model (4) and conduct a further robustness test. In addition to ensuring that the main results are statistically robust, we re-investigate the joint market liquidity timing ability of hedge funds at the strategy level using the bootstrap approach.

\subsection{Controlling for market return and volatility timings}

This paper focuses on debt-oriented hedge fund managers who use both fixed income market and equity market liquidities to forecast their beta in the focus market. Even so, Chen and Liang (2007) show that hedge fund managers could also use other market information for timing purposes, such as market return and volatility. This leads to the extension of model (3) to the following forecast model for the fixed income focus market:

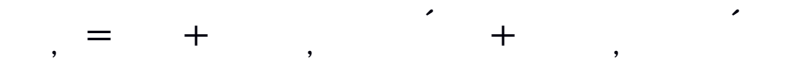

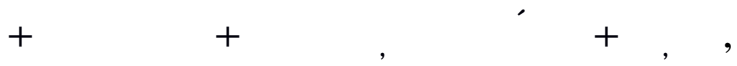

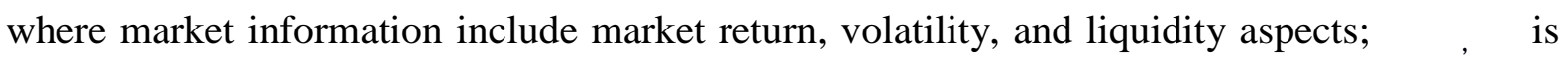
the realized fixed income market volatility; and †़ फ़ु, is the corresponding mean. Substituting the above forecast model into the seven-factor model of Fung and Hsieh (2004) produces the following extended JMLT model:

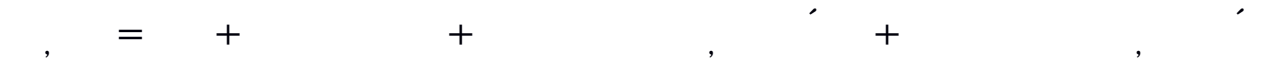

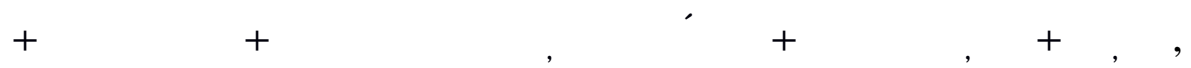




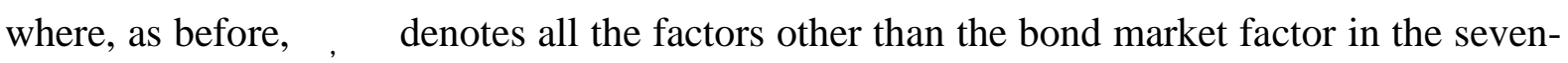
factor model. Following Chen and Liang (2007), the coefficients 5 and $ठ$ in model (6) measure market return-timing and volatility timing skills in the fixed income market, respectively.

Model (6) is an extension of the model of Chen and Liang (2007): Here market return and volatility timings are included alongside joint liquidity timing. Model (6) also extends model (4), which focuses only on liquidity timing. Table 7 reports the empirical results for model (6).

[Table 7]

Table 7 shows that both e and $\circlearrowright$ for long-only debt and fund of fund debt categories are not significant. This implies the hedge fund managers in these two strategy categories focus on fixed income market and equity market liquidity conditions for their timings, rather than market return timing and volatility timing. The results also show that the findings on joint timing equity and fixed income liquidity obtained in the previous section cannot be attributed to market return timing and volatility timing skills.

Table 7 also shows that, for the long/short debt strategy category, there is strong evidence of both liquidity and volatility timing ability. The debt arbitrage strategy category exhibits return timing ability in addition to liquidity and volatility timing. The results in Table 7 suggest that including the regressors of return timing and volatility timing does not affect the significance of liquidity timing ability, indicating the robustness of the main results obtained earlier. Interestingly, the results also indicate that, apart from liquidity timing, hedge 
funds in the long/short debt and debt arbitrage strategy categories also use other timing approaches to manage their investment exposures.

\subsection{Bootstrap analysis}

This subsection conducts a bootstrap ${ }^{17}$ analysis on our main findings reported in Section 3.1. We test whether the $t$-statistics of the liquidity timing coefficients for the actual hedge funds are statistically different from those bootstrapped hedge funds without liquidity timing skills. Regression analysis using a bootstrap approach ensures the results are valid with no normality assumption. We bootstrap the $t$-statistics rather than the liquidity timing coefficients because the $t$-statistics are pivotal (Chen and Liang, 2007).

The bootstrap analysis is carried out as follows. First, for hedge fund returns in a certain strategy category य़, we run the JMLT model (4). We save the estimated coefficients

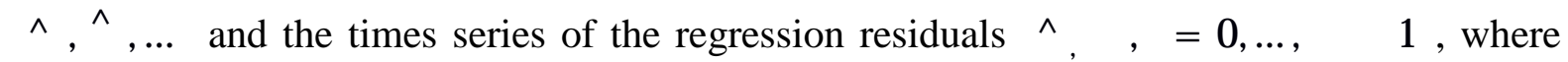
$\breve{\Gamma}_{\Omega}$ denotes the number of monthly returns for the hedge fund category. Next, we randomly resample the residuals with replacements and generate the time series of the residuals ( $=1,2, \ldots, \Phi)$. This results in hypothetical monthly excess returns by setting the liquidity timing coefficients to zero, that is,

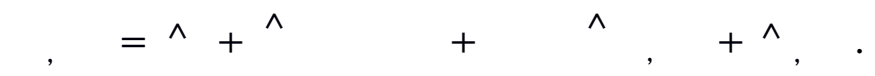

Next, we estimate the JMLT model (4) and calculate the corresponding $t$-statistics by employing the hypothetical monthly excess returns $\mathrm{c}_{3, n_{p}}$ We repeat this process 8 times (ष is set at 10,000 ) to obtain hypothetical distributions of cross-sectional $t$-statistics. The $p$-value

\footnotetext{
17 See Efron (1979) and Davidson and Hinkley (1997) for an overview of bootstrap methods.
} 
for a given statistic is defined as the frequency at which the statistical values of hypothetical hedge funds from ष time simulations exceeds the statistical value from the actual hedge fund categories.

[Table 8]

Table 8 presents the bootstrap analysis results of hedge fund managers' liquidity timing skills in the fixed income market for each strategy category. We obtain the reported $p$ values using the bootstrap resampling without imposing a normality assumption. Table 8 shows that the $p$-values of the two timing ability coefficients are less than $10 \%$ for the 'Longonly' hedge fund strategy category. This result further strengthens our findings that hedge fund managers in this strategy category exhibit the ability to jointly time fixed income market and equity market liquidity. Hedge fund managers in long/short debt and debt arbitrage categories, on the other hand, only exhibit the ability to time fixed income market liquidity. These findings are consistent with those reported in Table 3. However, for the fund of fund debt category, all p-values in Table 8 are greater than the $10 \%$ level.

\section{Conclusions}

The ability to invest with fewer restrictions than those confronting mutual funds has allowed hedge funds to take positions in sophisticated strategies, leading to more refined market timing. In fact, evidence of the market timing ability of equity-oriented hedge funds is found by Chincarini and Nakao (2011) and Chincarini (2014), while Cao, et al. (2013) reveal that equity-oriented hedge fund managers have equity market liquidity timing ability. The 2008 credit crisis sent a clear message on the importance of liquidity conditions in the investment management process, which motivated our paper to focus on the liquidity timing 
skills of debt-oriented hedge funds, an area not previously subject to academic investigation. We note that equity and bond markets are the two most commonly transacted markets by hedge funds, an observation that further motivated this exploration into liquidity timing ability and the likelihood of debt-oriented hedge funds exploiting the co-movements of debt and equity markets' liquidities to jointly time liquidities in these two markets. We tested this hypothesis at both the aggregate (strategy) and individual fund levels and also conducted a separate bootstrap analysis to verify our findings.

Our findings show evidence of liquidity timing ability in the fixed income market for all debt-oriented hedge fund strategy categories under investigation. Among these, long-only debt hedge funds managers reveal joint timing ability for the fixed income market liquidity and equity market liquidity, showing that correlation of the liquidities of the fixed income and equity markets provides useful information for the long-only debt hedge fund managers in managing market exposure. For diversifying or reducing downside losses, the equity market is a potential market for long-only debt hedge fund managers to transact in, given that this market largely uses a similar buy-and-hold strategy. Other debt-oriented hedge funds, such as long/short debt and debt arbitrage, appear to be adopting volatility timing and/or return timing, alongside fixed income market liquidity timing, rather than joint market liquidity timing. This could be explained by the flexibility of the strategies they adopt, allowing them to further diversify or reduce downside losses effectively. We also investigated the period after the financial crisis, that is, July 2007 to December 2012. This analysis indicates that expected change in the liquidity condition of the debt market during this period was an important factor in determining debt-oriented hedge fund performance outcomes. 
This paper has highlighted the importance of incorporating fixed income and equity market liquidity conditions in regard to debt-oriented hedge fund investment decision-making. Our findings show that some categories of debt-oriented hedge funds simultaneously possess volatility, return, and market liquidity timing skills and, therefore, these debt-oriented hedge fund managers appear to use a combination of timing strategies in their investment management. The ability of hedge funds to invest with fewer restrictions allows them to adopt sophisticated strategies that include market timing. It would be interesting to study if other strategy-type hedge funds are also able to actively time their markets based on different market information sets. Further investigation of these issues remains an area for future research.

\section{References}

Ackermann, C., McEnally, R., and Ravenscraft, D., 'The performance of hedge funds: risk, return, and incentives’, Journal of Finance, Vol. 54, 1999, pp. 833-74.

Agarwal, V., Fos, V. and Jiang W., 'Inferring reporting-related biases in hedge fund databases from hedge fund equity holdings', Management Science, Vol. 59, 2013, pp. 1271-89.

Aggarwal, R. K. and Jorion, P., 'The performance of emerging hedge funds and managers', Journal of Financial Economics, Vol. 96 (2), 2010, pp. 238-56.

Avramov, D., Kosowski, R., Naik, N. Y. and Teo, M., 'Hedge fund, managerial skill, and macroeconomic variables’, Journal of Financial Economics, Vol. 99, 2011, pp. 672-92.

Bali, T. G., Brown, S. J. and Caglayan, M. O., 'Do hedge funds' exposures to risk factors predict their future returns?' Journal of Financial Economics, Vol. 101 (1), 2011, pp. 3668. 
Ben-David, I., Franzoni, F. and Moussawi, R., 'Hedge fund stock trading in the financial crisis of 2007-2009’, Review of Financial Studies, Vol. 25, 2012, pp. 1-54.

Billio, M., Getmansky, M. and Pelizzon, L., 'Crises and hedge fund risk’, Working Paper (University of Venice and University of Massachusetts, 2009).

Busse, J., 'Volatility timing in mutual funds: evidence from daily returns', Review of Financial Studies, Vol. 12, 1999, pp. 1009-41.

Cao, C., Chen, Y., Liang, B. and Lo, A.W., 'Can hedge funds time market liquidity?’ Journal of Financial Economics, Vol. 109, 2013, pp. 493-516.

Chen, Y., 'Timing ability in the focus market of hedge funds', Journal of Investment Management, Vol. 5, 2007, pp. 66-98.

Chen, Y. and Liang, B., 'Do market timing hedge funds time the market?’ Journal of Financial and Quantitative Analysis, Vol. 42, 2007, pp. 827-56.

Chincarini, L., 'The impact of quantitative methods on hedge fund performance', European Financial Management, Vol. 20 (5), 2014, pp. 857-90.

Chincarini, L. B. and Nakao, A., 'Measuring hedge fund timing ability across factors', Journal of Investing, Vol. 20 (4), 2011, pp. 50-70.

Chordia, T., Sarkar, A. and Subrahmanyam, A., 'An empirical analysis of stock and bond market liquidity’, Review of Financial Studies, Vol. 18, 2005, pp. 85-129.

Davidson, A. C. and Hinkley, D. V., Bootstrap Methods and Their Application (Cambridge University Press, Cambridge, 1997).

Efron, B., 'Bootstrap methods: another look at the jackknife', Annals of Statistics, Vol. 7 (1), 1979, pp. 1-26.

Eling, M. and Faust, R., 'The performance of hedge funds and mutual funds in emerging markets’, Journal of Banking and Finance, Vol. 34, 2010, pp. 1993-2009. 
Ferson, W. and Schadt, R., 'Measuring fund strategy and performance in changing economic conditions', Journal of Finance, Vol. 51, 1996, pp. 425-60.

Fidelity Investment, 'Bond market: Resetting expectations in a post-QE world', 2014. Last accessed May 2015, http://www.fidelityecompendium.com/archive/2014/q4/ articles/2014/q4/financial-markets/bond-market-post-qe-world/index.shtml.

French, C. W. and Ko, D. B., 'How hedge funds beat the market', Journal of Investment Management, Vol. 5 (2), 2007, pp. 112-25.

Fung, W. and Hsieh, D. A., 'Empirical characteristics of dynamic trading strategies: the case of hedge funds’, Review of Financial Studies, Vol. 10, 1997, pp. 275-302.

Fung, W. and Hsieh, D. A., 'Performance characteristics of hedge funds and commodity funds: natural vs. spurious biases’, Journal of Financial and Quantitative Analysis, Vol. 35, 2000, pp. 291-307.

Fung, W. and Hsieh, D. A., 'The risk in hedge fund strategies: theory and evidence from trend followers', Review of Financial Studies, Vol. 14 (2), 2001, pp. 313-41.

Fung, W. and Hsieh, D. A., 'Hedge fund benchmarks: a risk-based approach', Financial Analyst Journal, Vol. 60, 2004, pp. 65-80.

Fung, W. and Hsieh, D. A., 'The risk in hedge fund strategies: theory and evidence from long/short equity hedge funds', Journal of Empirical Finance, Vol. 18, 2011, pp. 547-69.

Gintschel, A. and Wiehenkamp, C., 'A global liquidity factor for fixed income pricing', Working Paper (Goethe University Frankfurt, 2009).

Goyenko, R.Y., and Ukhov, A.D., 'Stock and Bond Market Liquidity: A Long-Run Empirical Analysis', Journal of Financial and Quantitative Analysis, Vol. 44(1), 2009, pp.189-212 
Joenväärä, J., Kosowski, R. and Tolonen, P., 'Hedge fund performance: what do we know?’ Working Paper (Social Science Research Network, 2013), available at http://dx. doi.org/10.2139/ssrn.1989410.

Kessler, S. and Scherer, B., 'Hedge funds return sensitivity to global liquidity', Journal of Financial Markets, Vol. 14 (2), 2011, pp. 301-22.

Khandani, A. E. and Lo, A. W., 'What happened to the quants in August 2007? Evidence from factors and transaction data', Journal of Financial Markets, Vol. 14(1), 2011, pp. 146.

Longstaff, F. A., Mithal, S. and Neis, E., 'Corporate yield spreads: default risk or liquidity? New evidence from the credit default swap market', Journal of Finance, Vol. 60, 2005, pp. 2213-53.

Morningstar, 'The Morningstar category classifications for hedge funds', 2014. Last accessed March 2015, http://corporate.morningstar.com/uk/documents/MethodologyDocuments/ MethodologyPapers/MorningstarHedgeFundCategories_Methodology.pdf.

Park, H., 'Can factor timing explain hedge funds alpha?' Working Paper (Minnesota State University, 2010).

Pastor, L. and Stambaugh, R. F., 'Liquidity risk and expected stock returns', Journal of Political Economy, Vol. 111, 2003, pp. 642-85.

Patton, A. J. and Ramadorai, T., 'On the high-frequency dynamics of hedge fund risk exposures', Journal of Finance, Vol. 68(2), 2013, pp. 597-635.

Sadka, R., 'Liquidity risk and the cross-section of hedge-fund returns', Journal of Financial Economics, Vol. 98, 2010, pp. 54-71.

Shanken, J., 'Intertemporal asset pricing: an empirical investigation', Journal of Econometrics, Vol. 45, 1990, pp. 99-120. 
Stefanova, D. and Siegmann, A., 'Market liquidity and exposure of hedge funds', Working Paper (VU University Amsterdam, 2012).

Treynor, J. and Mazuy, K., 'Can mutual funds outguess the market?' Harvard Business Review, Vol. 44, 1966, pp. 131-36. 
Table 1

\section{Summary statistics of the data}

This table reports the summary statistics. Panel A reports the debt-oriented hedge funds' returns computed from data obtained from Morningstar (2014), where $\mathrm{N}$ is the number of funds that exist at any time during the sample period. Panel B reports the summary statistics of the seven-factor model data (Fung and Hsieh, 2004), which includes market excess return (EMF), a size factor (SMB), the negative monthly change in the 10-year Treasury constant maturity yield (BMF), the monthly change in the Moody's Baa yield less the 10-year Treasury constant maturity yield (CSF), and three trendfollowing factors, namely, PFTSBD (bond), PFTSFX (currency), and PFTSCOM (commodity). The variable bond market factor, BMF, used is defined as the negative monthly change in the 10-year Treasury constant maturity yield. Panel C reports the summary statistics of liquidity measures, which include Pastor-Stambaugh, the equity market liquidity measure based on that of Pastor and Stambaugh (2003); LFI10-15Y, the fixed income market liquidity measure calculated as the difference between the excess rate of the BBB rated BofA Merrill Lynch US Corporate bonds for 1015 years and the 10-year CDX credit spread; LFI7-10Y, the fixed income market liquidity measure calculated as the difference between the excess rate of the BBB rated BofA Merrill Lynch US Corporate bonds for seven to 10 years and the 10-year CDX credit spread; and LFI5-10Y, the fixed income market liquidity measure calculated as the difference between the excess rate of the BBB rated BofA Merrill Lynch US Corporate bonds for five to 10 years and the five-year CDX credit spread.

\begin{tabular}{|c|c|c|c|c|c|c|}
\hline Variables & $\bar{N}$ & Mean & Median & $\begin{array}{c}\text { Standard } \\
\text { Deviation }\end{array}$ & $25 \%$ & $75 \%$ \\
\hline \multicolumn{7}{|c|}{ Panel A: Summary of debt-oriented hedge funds' returns } \\
\hline Long-Only Debt & 102 & 0.412 & 0.515 & 1.287 & -0.082 & 0.996 \\
\hline Long/Short Debt & 429 & 0.487 & 0.652 & 1.321 & 0.064 & 1.014 \\
\hline Debt Arbitrage & 217 & 0.342 & 0.479 & 1.099 & 0.122 & 0.838 \\
\hline Fund of Fund Debt & 221 & 0.187 & 0.531 & 1.446 & -0.287 & 0.999 \\
\hline \multicolumn{7}{|c|}{ Panel B: Summary of factor data } \\
\hline EMF & & 0.315 & 0.938 & 4.587 & -1.917 & 3.093 \\
\hline SMB & & 0.150 & -0.048 & 2.475 & -1.418 & 1.375 \\
\hline BMF & & 0.027 & 0.015 & 0.270 & -0.138 & 0.183 \\
\hline CSF & & 0.013 & 0.000 & 0.292 & -0.100 & 0.100 \\
\hline PTFSBD & & -3.659 & -6.575 & 15.355 & -14.190 & 1.860 \\
\hline PTFSFX & & -0.834 & -5.635 & 20.101 & -16.508 & 7.580 \\
\hline PTFSCOM & & -0.747 & -3.055 & 14.498 & -9.885 & 6.165 \\
\hline \multicolumn{7}{|c|}{ Panel C: Summary of liquidity measures } \\
\hline Pastor-Stambaugh & & -0.026 & -0.013 & 0.076 & -0.059 & 0.018 \\
\hline LFI10-15Y & & -1.583 & -1.333 & 0.979 & -1.633 & -0.956 \\
\hline LFI7-10Y & & -1.883 & -1.536 & 1.230 & -2.015 & -1.172 \\
\hline LFI5-10Y & & -2.240 & -2.131 & 1.258 & -2.501 & -1.562 \\
\hline
\end{tabular}


Table 2

Correlations between the liquidity measures

This table reports the Pearson correlation coefficients in the full sample and for the recent financial crisis periods, respectively. The measure of the equity market liquidity Pastor-Stambaugh is calculated based on that of Pastor and Stambaugh (2003). The measure of fixed income market liquidity LFI10$15 \mathrm{Y}$ is calculated as the difference between the excess rate of the BBB rated BofA Merrill Lynch US Corporate bonds for 10-15 years and the 10-year CDX credit spread. The measure of fixed income market liquidity LFI7-10Y is calculated as the difference between the excess rate of the BBB rated BofA Merrill Lynch US Corporate bonds for seven to 10 years and the 10year CDX credit spread. The measure of fixed income market liquidity LFI5-10Y is calculated as the difference between the excess rate of the BBB rated BofA Merrill Lynch US Corporate bonds for five to 10 years and the five-year CDX credit spread. The numbers in parentheses are $p$-values. The superscripts $*, * *$, and $* * *$ indicate that the correlation is significantly different from zero at the $10 \%, 5 \%$, and $1 \%$ levels, respectively.

\begin{tabular}{|c|c|c|c|c|}
\hline & $\begin{array}{c}\text { Pastor- } \\
\text { Stambaugh }\end{array}$ & LIF10-15 & LIF7-10 & LIF5-10 \\
\hline & \multicolumn{4}{|c|}{ Entire time period (March 2005 to Dec. 2012) } \\
\hline $\begin{array}{l}\text { Pastor- } \\
\text { Stambaugh }\end{array}$ & 1 & & & \\
\hline LIF10-15 & $\begin{array}{c}0.383 \\
\left(0.000^{* * *}\right)\end{array}$ & 1 & & \\
\hline LIF7-10 & $\begin{array}{c}0.406 \\
\left(0.000^{* * *}\right)\end{array}$ & $\begin{array}{c}0.988 \\
\left(0.000^{* * *}\right)\end{array}$ & 1 & \\
\hline \multirow[t]{2}{*}{ LIF5-10 } & $\begin{array}{c}0.346 \\
\left(0.001^{* * *}\right)\end{array}$ & $\begin{array}{c}0.959 \\
\left(0.000^{* * *}\right) \\
\end{array}$ & $\begin{array}{c}0.930 \\
\left(0.000^{* * *}\right)\end{array}$ & 1 \\
\hline & \multicolumn{4}{|c|}{ Financial crisis time period (July 2007 to Dec. 2012) } \\
\hline $\begin{array}{l}\text { Pastor- } \\
\text { Stambaugh }\end{array}$ & 1 & & & \\
\hline LIF10-15 & $\begin{array}{c}0.378 \\
\left(0.002^{* * *}\right)\end{array}$ & 1 & & \\
\hline LIF7-10 & $\begin{array}{c}0.409 \\
\left(0.001^{* * *}\right)\end{array}$ & $\begin{array}{c}0.990 \\
\left(0.000^{* * *}\right)\end{array}$ & 1 & \\
\hline LIF5-10 & $\begin{array}{c}0.331 \\
\left(0.007^{* * *}\right)\end{array}$ & $\begin{array}{c}0.979 \\
\left(0.000^{* * *}\right)\end{array}$ & $\begin{array}{c}0.968 \\
\left(0.000^{* * *}\right)\end{array}$ & 1 \\
\hline
\end{tabular}


Table 3

Coefficient estimates of the JMLT model

This table reports the coefficients and $t$-statistics for the JMLT model (4). The first column contains the results combining debt-oriented funds that include the long-only debt, long/short debt, and debt arbitrage strategy categories. The fund of fund debt category is not included to avoid possible double counting. The coefficient $\bar{\Sigma}$ measures fixed income market liquidity timing ability and 3 measures equity market liquidity timing ability. The measures of fixed income market liquidity LFI10-15Y, LFI7-10Y, and LFI5-10Y are used in each of the three panels, respectively, where the measure of equity market liquidity Pastor-Stambaugh is calculated based on that of Pastor and Stambaugh (2003). The measure of fixed income market liquidity LFI10-15Y is calculated as the difference between the excess rate of the BBB rated BofA Merrill Lynch US Corporate bond for 10-15 years and the 10-year CDX credit spread. The measure of fixed income market liquidity LFI7-10Y is calculated as the difference between the excess rate of the BBB rated BofA Merrill Lynch US Corporate bond for seven to 10 years and the 10 -year CDX credit spread. The measure of fixed income market liquidity LFI5-10Y is calculated as the difference between the excess rates of the BBB rated BofA Merrill Lynch US Corporate bond for five to 10 years and the five-year CDX credit spread. The numbers in parentheses are $t$-statistics. The superscripts *, **, and *** indicate that the coefficient is significantly different from zero at the $10 \%, 5 \%$, and $1 \%$ levels, respectively.

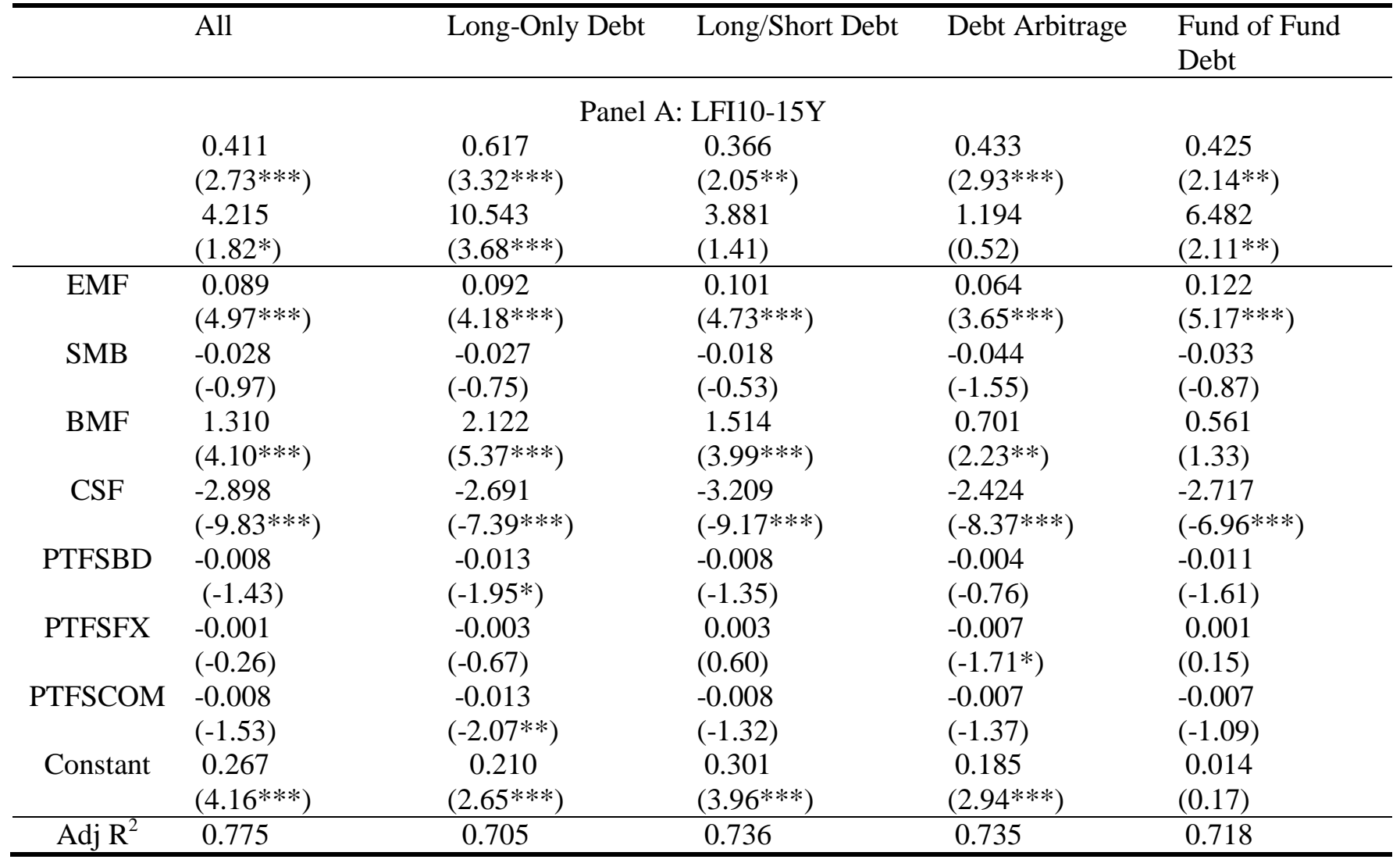


Table 3

continued

\begin{tabular}{|c|c|c|c|c|c|}
\hline & All & Long-Only Debt & Long/Short Debt & Debt Arbitrage & $\begin{array}{l}\text { Fund of Fund } \\
\text { Debt }\end{array}$ \\
\hline \multicolumn{6}{|c|}{ Panel B: LFI7-10Y } \\
\hline $\bar{c}$ & $\begin{array}{l}0.334 \\
\left(2.94^{* * *}\right)\end{array}$ & $\begin{array}{c}0.493 \\
\left(3.51^{* * *}\right)\end{array}$ & $\begin{array}{l}0.294 \\
\left(2.17^{* *}\right)\end{array}$ & $\begin{array}{l}0.354 \\
\left(3.17^{* * *}\right)\end{array}$ & $\begin{array}{l}0.353 \\
\left(2.34^{* *}\right)\end{array}$ \\
\hline उ & $\begin{array}{l}4.243 \\
\left(1.85^{*}\right)\end{array}$ & $\begin{array}{l}10.623 \\
(3.75 * * *)\end{array}$ & $\begin{array}{r}3.920 \\
(1.43)\end{array}$ & $\begin{array}{l}1.214 \\
(0.54)\end{array}$ & $\begin{array}{l}6.482 \\
\left(2.13^{* *}\right)\end{array}$ \\
\hline MKT & $\begin{array}{l}0.090 \\
\left(5.05^{* * *}\right)\end{array}$ & $\begin{array}{c}0.094 \\
\left(4.26^{* * *}\right)\end{array}$ & $\begin{array}{l}0.101 \\
\left(4.78^{* * *}\right)\end{array}$ & $\begin{array}{l}0.065 \\
\left(3.74^{* * *}\right)\end{array}$ & $\begin{array}{c}0.123 \\
(5.24 * * *)\end{array}$ \\
\hline SMB & $\begin{array}{l}-0.028 \\
(-0.98)\end{array}$ & $\begin{array}{l}-0.0277 \\
(-0.78)\end{array}$ & $\begin{array}{l}-0.019 \\
(-0.54)\end{array}$ & $\begin{array}{l}-0.045 \\
(-1.57)\end{array}$ & $\begin{array}{l}-0.034 \\
(-0.88)\end{array}$ \\
\hline BMF & $\begin{array}{l}1.340 \\
\left(4.20^{* * *}\right)\end{array}$ & $\begin{array}{l}2.156 \\
(5.48 * * *)\end{array}$ & $\begin{array}{l}1.536 \\
\left(4.05^{* * *}\right)\end{array}$ & $\begin{array}{c}0.734 \\
\left(2.35^{* *}\right)\end{array}$ & $\begin{array}{r}0.599 \\
(1.42)\end{array}$ \\
\hline CSF & $\begin{array}{l}-2.902 \\
(-9.92 * * *)\end{array}$ & $\begin{array}{l}-2.670 \\
(-7.47 * * *)\end{array}$ & $\begin{array}{l}-3.213 \\
(-9.22 * * *)\end{array}$ & $\begin{array}{l}-2.427 \\
\left(-8.46^{* * *}\right)\end{array}$ & $\begin{array}{l}-2.719 \\
(-7.02 * * *)\end{array}$ \\
\hline PTFSBD & $\begin{array}{l}-0.008 \\
(-1.49)\end{array}$ & $\begin{array}{l}-0.013 \\
\left(-2.04^{* *}\right)\end{array}$ & $\begin{array}{l}-0.009 \\
(-1.40)\end{array}$ & $\begin{array}{l}-0.004 \\
(-0.81)\end{array}$ & $\begin{array}{l}-0.011 \\
(-1.66)\end{array}$ \\
\hline PTFSFX & $\begin{array}{l}-0.001 \\
(-0.24)\end{array}$ & $\begin{array}{l}-0.003 \\
(-0.65)\end{array}$ & $\begin{array}{r}0.003 \\
(0.61)\end{array}$ & $\begin{array}{l}-0.007 \\
\left(-1.71^{*}\right)\end{array}$ & $\begin{array}{r}0.001 \\
(0.17)\end{array}$ \\
\hline PTFSCOM & $\begin{array}{l}-0.008 \\
(-1.55)\end{array}$ & $\begin{array}{l}-0.013 \\
(-2.09 * *)\end{array}$ & $\begin{array}{l}-0.008 \\
(-1.34)\end{array}$ & $\begin{array}{l}-0.007 \\
(-1.40)\end{array}$ & $\begin{array}{l}-0.007 \\
(-1.11)\end{array}$ \\
\hline Constant & $\begin{array}{l}0.265 \\
\left(4.16^{* * *}\right)\end{array}$ & $\begin{array}{l}0.207 \\
\left(2.63^{* * *}\right)\end{array}$ & $\begin{array}{l}0.300 \\
\left(3.95^{* * *}\right)\end{array}$ & $\begin{array}{l}0.184 \\
(2.94 * * *)\end{array}$ & $\begin{array}{r}0.013 \\
(0.15)\end{array}$ \\
\hline \multirow[t]{2}{*}{ Adj $R^{2}$} & 0.778 & 0.708 & 0.738 & 0.739 & 0.721 \\
\hline & & Panel & LFI5-10Y & & \\
\hline $\bar{\varepsilon}$ & $\begin{array}{l}0.286 \\
\left(2.34^{* *}\right)\end{array}$ & $\begin{array}{l}0.493 \\
\left(3.51^{* * *}\right)\end{array}$ & $\begin{array}{l}0.294 \\
\left(2.17^{* *}\right)\end{array}$ & $\begin{array}{l}0.354 \\
\left(3.17^{* * *}\right)\end{array}$ & $\begin{array}{l}0.353 \\
(2.34 * *)\end{array}$ \\
\hline उ & $\begin{array}{c}4.698 \\
\left(2.03^{* *}\right) \\
\end{array}$ & $\begin{array}{l}10.623 \\
\left(3.75^{* * *}\right)\end{array}$ & $\begin{array}{r}3.920 \\
(1.43) \\
\end{array}$ & $\begin{array}{r}1.214 \\
(0.54) \\
\end{array}$ & $\begin{array}{c}6.482 \\
\left(2.13^{* *}\right)\end{array}$ \\
\hline MKT & $\begin{array}{l}0.088 \\
(4.84 * * *)\end{array}$ & $\begin{array}{c}0.094 \\
\left(4.26^{* * *}\right)\end{array}$ & $\begin{array}{l}0.101 \\
\left(4.78^{* * *}\right)\end{array}$ & $\begin{array}{l}0.065 \\
\left(3.74^{* * *}\right)\end{array}$ & $\begin{array}{c}0.123 \\
(5.24 * * *)\end{array}$ \\
\hline SMB & $\begin{array}{l}-0.031 \\
(-1.05)\end{array}$ & $\begin{array}{r}-0.0277 \\
(-0.78)\end{array}$ & $\begin{array}{l}-0.019 \\
(-0.54)\end{array}$ & $\begin{array}{l}-0.045 \\
(-1.57)\end{array}$ & $\begin{array}{l}-0.034 \\
(-0.88)\end{array}$ \\
\hline BMF & $\begin{array}{l}1.263 \\
\left(3.91^{* * *}\right)\end{array}$ & $\begin{array}{l}2.156 \\
\left(5.48^{* * *}\right)\end{array}$ & $\begin{array}{l}1.536 \\
\left(4.05^{* * *}\right)\end{array}$ & $\begin{array}{c}0.734 \\
\left(2.35^{* *}\right)\end{array}$ & $\begin{array}{l}0.599 \\
(1.42)\end{array}$ \\
\hline CSF & $\begin{array}{l}-2.907 \\
(-9.74 * * *)\end{array}$ & $\begin{array}{l}-2.670 \\
\left(-7.47^{* * *}\right)\end{array}$ & $\begin{array}{l}-3.213 \\
(-9.22 * * *)\end{array}$ & $\begin{array}{l}-2.427 \\
(-8.46 * * *)\end{array}$ & $\begin{array}{l}-2.719 \\
(-7.02 * * *)\end{array}$ \\
\hline PTFSBD & $\begin{array}{l}-0.007 \\
(-1.40)\end{array}$ & $\begin{array}{l}-0.013 \\
\left(-2.04^{* *}\right)\end{array}$ & $\begin{array}{l}-0.009 \\
(-1.40)\end{array}$ & $\begin{array}{l}-0.004 \\
(-0.81)\end{array}$ & $\begin{array}{l}-0.011 \\
(-1.66)\end{array}$ \\
\hline PTFSFX & $\begin{array}{l}-0.001 \\
(-0.27)\end{array}$ & $\begin{array}{l}-0.003 \\
(-0.65)\end{array}$ & $\begin{array}{c}0.003 \\
(0.61)\end{array}$ & $\begin{array}{l}-0.007 \\
\left(-1.71^{*}\right)\end{array}$ & $\begin{array}{c}0.001 \\
(0.17)\end{array}$ \\
\hline PTFSCOM & $\begin{array}{l}-0.007 \\
(-1.49)\end{array}$ & $\begin{array}{l}-0.013 \\
(-2.09 * *)\end{array}$ & $\begin{array}{l}-0.008 \\
(-1.34)\end{array}$ & $\begin{array}{l}-0.007 \\
(-1.40)\end{array}$ & $\begin{array}{l}-0.007 \\
(-1.11)\end{array}$ \\
\hline Constant & $\begin{array}{c}0.270 \\
\left(4.16^{* * *}\right) \\
\end{array}$ & $\begin{array}{l}0.207 \\
\left(2.63^{* * *}\right)\end{array}$ & $\begin{array}{l}0.300 \\
\left(3.95^{* * *}\right)\end{array}$ & $\begin{array}{l}0.184 \\
\left(2.94^{* * *}\right)\end{array}$ & $\begin{array}{r}0.013 \\
(0.15) \\
\end{array}$ \\
\hline Adj $R^{2}$ & 0.770 & 0.708 & 0.738 & 0.739 & 0.721 \\
\hline
\end{tabular}


Table 4

Coefficient estimates of the JMLT model, controlling for backfill bias

This table reports the main coefficient estimates for the JMLT model (4), controlling for backfill bias. The coefficient $\bar{\Sigma}$ measures fixed income market liquidity timing ability and 3 measures equity market liquidity timing ability. The measure of equity market liquidity Pastor-Stambaugh is calculated based on that of Pastor and Stambaugh (2003). The measure of fixed income market liquidity LFI10-15Y is calculated as the difference between the excess rate of the BBB rated BofA Merrill Lynch US Corporate bonds for 10-15 years and the 10-year CDX credit spread. The measure of fixed income market liquidity LFI7-10Y is calculated as the difference between the excess rate of the BBB rated BofA Merrill Lynch US Corporate bonds for seven to 10 years and the 10-year CDX credit spread. The measure of fixed income market liquidity LFI5-10Y is calculated as the difference between the excess rate of the BBB rated BofA Merrill Lynch US Corporate bonds for five to 10 years and the five-year CDX credit spread. The numbers in parentheses are $t$-statistics. The superscripts $*, * *$, and $* * *$ indicate that the coefficient is significantly different from zero at the $10 \%$, $5 \%$, and $1 \%$ levels, respectively.

\begin{tabular}{lllllll}
\hline & LFI10-15Y & \multicolumn{3}{c}{ LFI7-10Y } & \multicolumn{3}{c}{ LFI5-10Y } \\
& $\overline{1}$ & $\Xi$ & $\overline{10}$ & उ & $\bar{\Sigma}$ & उ \\
\hline Long-Only Debt & 0.589 & 15.923 & 0.486 & 15.931 & 0.442 & 16.509 \\
& $\left(2.85^{* * *}\right)$ & $\left(4.99^{* * *}\right)$ & $\left(3.12^{* * *}\right)$ & $\left(5.06^{* * *}\right)$ & $\left(2.64^{* * *}\right)$ & $\left(5.20^{* * *}\right)$ \\
Long Short Debt & 0.341 & 4.757 & 0.275 & 4.788 & 0.225 & 5.198 \\
& $\left(1.77^{*}\right)$ & $(1.60)$ & $\left(1.88^{*}\right)$ & $(1.62)$ & $(1.44)$ & $\left(1.76^{*}\right)$ \\
Debt Arbitrage & 0.464 & 1.424 & 0.383 & 1.432 & 0.319 & 1.981 \\
& $\left(2.68^{* * *}\right)$ & $(0.53)$ & $\left(2.92^{* * *}\right)$ & $(0.54)$ & $\left(2.27^{* *}\right)$ & $(0.74)$ \\
Fund of Fund Debt & 0.441 & 6.737 & 0.365 & 6.740 & 0.318 & 7.220 \\
& $\left(2.14^{* *}\right)$ & $\left(2.12^{* *}\right)$ & $\left(2.34^{* *}\right)$ & $\left(2.14^{* *}\right)$ & $\left(1.91^{*}\right)$ & $\left(2.29^{* *}\right)$ \\
\hline
\end{tabular}


Table 5

Coefficient estimates of the JMLT model around the financial crisis period,

July 2007 to December 2012

This table reports the main coefficient estimates of the JMLT model (4) around the recent financial crisis period (July 2007 to December 2012). The measure of equity market liquidity PastorStambaugh is calculated based on that of Pastor and Stambaugh (2003). The measure of fixed income market liquidity LFI10-15Y is calculated as the difference between the excess rate of the BBB rated BofA Merrill Lynch US Corporate bonds for 10-15 years and the 10-year CDX credit spread. The measure of fixed income market liquidity LFI7-10Y is calculated as the difference between the excess rate of the BBB rated BofA Merrill Lynch US Corporate bonds for seven to 10 years and the 10-year CDX credit spread. The measure of fixed income market liquidity LFI5-10Y is calculated as the difference between the excess rate of the BBB rated BofA Merrill Lynch US Corporate bond for five to 10 years and the five-year CDX credit spread. The numbers in parentheses are $t$-statistics. The superscripts $*, * *$, and $* * *$ indicate that the coefficient is significantly different from zero at the $10 \%, 5 \%$, and $1 \%$ levels, respectively.

\begin{tabular}{|c|c|c|c|c|c|c|}
\hline & \multicolumn{2}{|c|}{ LFI10-15Y } & \multicolumn{2}{|c|}{ LFI7-10Y } & \multicolumn{2}{|c|}{ LFI5-10Y } \\
\hline & $\bar{\varepsilon}$ & उ & $\bar{\varepsilon}$ & उ & $\bar{\varepsilon}$ & उ \\
\hline Long-Only Debt & $\begin{array}{c}0.733 \\
(3.26 * * *)\end{array}$ & $\begin{array}{c}11.036 \\
\left(3.35^{* * *}\right)\end{array}$ & $\begin{array}{c}0.571 \\
\left(3.43^{* * *}\right)\end{array}$ & $\begin{array}{c}11.185 \\
\left(3.44^{* * *}\right)\end{array}$ & $\begin{array}{c}0.640 \\
(3.34 * * *)\end{array}$ & $\begin{array}{c}11.631 \\
(3.58 * * *)\end{array}$ \\
\hline Long/Short Debt & $\begin{array}{c}0.532 \\
\left(2.44^{* *}\right)\end{array}$ & $\begin{array}{l}3.499 \\
(1.10)\end{array}$ & $\begin{array}{c}0.406 \\
\left(2.50^{* *}\right)\end{array}$ & $\begin{array}{l}3.633 \\
(1.15)\end{array}$ & $\begin{array}{c}0.451 \\
\left(2.42^{* *}\right)\end{array}$ & $\begin{array}{l}3.961 \\
(1.25)\end{array}$ \\
\hline Debt Arbitrage & $\begin{array}{c}0.618 \\
\left(3.45^{* * *}\right)\end{array}$ & $\begin{array}{l}0.055 \\
(0.02)\end{array}$ & $\begin{array}{c}0.480 \\
\left(3.61^{* * *}\right)\end{array}$ & $\begin{array}{l}0.187 \\
(0.07)\end{array}$ & $\begin{array}{c}0.523 \\
\left(3.40^{* * *}\right)\end{array}$ & $\begin{array}{l}0.597 \\
(0.23)\end{array}$ \\
\hline Fund of Fund - Debt & $\begin{array}{c}0.614 \\
(2.62 *)\end{array}$ & $\begin{array}{l}4.780 \\
(1.40)\end{array}$ & $\begin{array}{c}0.481 \\
\left(2.77^{* * *}\right)\end{array}$ & $\begin{array}{l}4.914 \\
(1.45)\end{array}$ & $\begin{array}{c}0.540 \\
(2.70 * *)\end{array}$ & $\begin{array}{l}5.288 \\
(1.56)\end{array}$ \\
\hline
\end{tabular}


Table 6

Distributions of the t-statistics for cross-sectional individual hedge funds' liquidity timing coefficients

This table summarizes the distributions of the $t$-statistics for cross-sectional individual hedge funds' liquidity timing coefficient $\lambda$ (Panels A to C) and timing coefficient 3 (Panels D to F) in the JMLT model (4). The coefficient $\bar{\Sigma}$ measures fixed income market liquidity timing ability and 3 measures equity market liquidity timing ability. The measure of equity market liquidity Pastor-Stambaugh is based on that of Pastor and Stambaugh (2003). The measure of fixed income market liquidity LFI10$15 \mathrm{Y}$ is calculated as the difference between the excess rate of the BBB rated BofA Merrill Lynch US Corporate bonds for 10-15 years and the 10-year CDX credit spread. The measure of fixed income market liquidity LFI7-10Y is calculated as the difference between the excess rate of the BBB rated BofA Merrill Lynch US Corporate bonds for seven to 10 years and the 10-year CDX credit spread. The measure of fixed income market liquidity LFI5-10Y is calculated as the difference between the excess rate of the BBB rated BofA Merrill Lynch US Corporate bonds for five to 10 years and the five-year CDX credit spread.

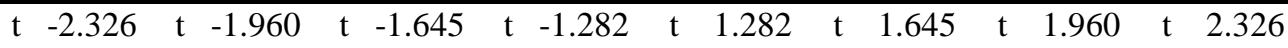

\begin{tabular}{|c|c|c|c|c|c|c|c|c|}
\hline \multicolumn{9}{|c|}{ Panel A: Distributions of t-statistics for $\bar{\Sigma}$ (LFI 10-15Y) } \\
\hline Long-Only Debt & 0.010 & 0.020 & 0.049 & 0.078 & 0.255 & 0.235 & 0.186 & 0.177 \\
\hline Long/Short Debt & 0.047 & 0.089 & 0.121 & 0.175 & 0.231 & 0.173 & 0.140 & 0.107 \\
\hline Debt Arbitrage & 0.060 & 0.148 & 0.221 & 0.244 & 0.258 & 0.198 & 0.152 & 0.124 \\
\hline Fund of Fund-Debt & 0.023 & 0.027 & 0.059 & 0.104 & 0.258 & 0.167 & 0.113 & 0.091 \\
\hline \multicolumn{9}{|c|}{ Panel B: Distributions of t-statistics for $\bar{\Sigma}$ (LFI 7-10Y) } \\
\hline Long-Only Debt & 0.000 & 0.010 & 0.049 & 0.069 & 0.265 & 0.216 & 0.196 & 0.177 \\
\hline Long/Short Debt & 0.047 & 0.072 & 0.100 & 0.154 & 0.215 & 0.163 & 0.138 & 0.112 \\
\hline Debt Arbitrage & 0.069 & 0.166 & 0.212 & 0.249 & 0.267 & 0.217 & 0.157 & 0.120 \\
\hline Fund of Fund-Debt & 0.018 & 0.032 & 0.050 & 0.081 & 0.276 & 0.199 & 0.127 & 0.100 \\
\hline \multicolumn{9}{|c|}{ Panel C: Distributions of t-statistics for $\bar{c}$ (LFI 5-10Y) } \\
\hline Long-Only Debt & 0.000 & 0.010 & 0.020 & 0.098 & 0.255 & 0.206 & 0.186 & 0.186 \\
\hline Long/Short Debt & 0.056 & 0.096 & 0.131 & 0.159 & 0.217 & 0.152 & 0.124 & 0.091 \\
\hline Debt Arbitrage & 0.065 & 0.161 & 0.217 & 0.254 & 0.277 & 0.226 & 0.157 & 0.129 \\
\hline Fund of Fund-Debt & 0.023 & 0.041 & 0.068 & 0.100 & 0.240 & 0.136 & 0.118 & 0.091 \\
\hline
\end{tabular}


Table 6

Continued

ta -2.326

ta -1.960

ta -1.645

ta -1.282

t Bं 1.282

t Bं 1.645

t B்1.960 t Bं 2.326

\begin{tabular}{|c|c|c|c|c|c|c|c|c|}
\hline \multicolumn{9}{|c|}{ Panel D: Distributions of t-statistics for उ (LFI 10-15Y) } \\
\hline Long-Only Debt & 0.039 & 0.069 & 0.098 & 0.098 & 0.324 & 0.275 & 0.245 & 0.216 \\
\hline Long/Short Debt & 0.030 & 0.040 & 0.070 & 0.112 & 0.191 & 0.138 & 0.089 & 0.061 \\
\hline Debt Arbitrage & 0.092 & 0.106 & 0.115 & 0.161 & 0.152 & 0.111 & 0.074 & 0.046 \\
\hline Fund of Fund-Debt & 0.009 & 0.018 & 0.041 & 0.068 & 0.335 & 0.158 & 0.104 & 0.077 \\
\hline \multicolumn{9}{|c|}{ Panel E: Distributions of t-statistics for उ (LFI 7-10Y) } \\
\hline Long-Only Debt & 0.049 & 0.069 & 0.098 & 0.108 & 0.333 & 0.284 & 0.265 & 0.216 \\
\hline Long/Short Debt & 0.030 & 0.040 & 0.061 & 0.105 & 0.191 & 0.131 & 0.091 & 0.061 \\
\hline Debt Arbitrage & 0.078 & 0.101 & 0.106 & 0.166 & 0.161 & 0.092 & 0.065 & 0.042 \\
\hline Fund of Fund-Debt & 0.009 & 0.018 & 0.032 & 0.086 & 0.308 & 0.154 & 0.109 & 0.077 \\
\hline \multicolumn{9}{|c|}{ Panel F: Distributions of t-statistics for उ (LFI 5-10Y) } \\
\hline Long-Only Debt & 0.039 & 0.069 & 0.108 & 0.108 & 0.324 & 0.294 & 0.265 & 0.216 \\
\hline Long/Short Debt & 0.028 & 0.040 & 0.065 & 0.100 & 0.208 & 0.140 & 0.103 & 0.068 \\
\hline Debt Arbitrage & 0.083 & 0.106 & 0.134 & 0.161 & 0.161 & 0.101 & 0.074 & 0.046 \\
\hline Fund of Fund-Debt & 0.009 & 0.018 & 0.049 & 0.077 & 0.335 & 0.195 & 0.122 & 0.077 \\
\hline
\end{tabular}




\section{Table 7}

\section{Coefficient estimates of the extended JMLT model}

This table reports the main coefficient estimates for the extended JMLT model (6). The coefficient $\bar{\Sigma}$ measures fixed income market liquidity timing ability and 3 measures equity market liquidity timing ability. The measure of equity market liquidity Pastor-Stambaugh is calculated based on that of Pastor and Stambaugh (2003). The measure of fixed income market liquidity LFI10-15Y is calculated as the difference between the excess rate of the BBB rated BofA Merrill Lynch US Corporate bonds for 10-15 years and the 10-year CDX credit spread. The measure of fixed income market liquidity LFI7-10Y is calculated as the difference between the excess rate of the BBB rated BofA Merrill Lynch US Corporate bonds for seven to 10 years and the 10-year CDX credit spread. The measure of fixed income market liquidity LFI5-10Y is calculated as the difference between the excess rate of the BBB rated BofA Merrill Lynch US Corporate bonds for five to 10 years and the five-year CDX credit spread. Coefficients 5 and $ठ$ measure market return timing and volatility timing abilities, respectively. The numbers in parentheses are $t$-statistics. The superscripts $*, * *$, and $* * *$ indicate that the coefficient is significantly different from zero at the $10 \%, 5 \%$, and $1 \%$ levels, respectively.

\begin{tabular}{|c|c|c|c|c|}
\hline & \multicolumn{4}{|c|}{ Panel A: LFI10-15Y } \\
\hline & $\Sigma$ & उ & जा & ठ \\
\hline \multirow[t]{2}{*}{ Long-Only Debt } & 0.765 & 10.365 & -0.625 & -18.113 \\
\hline & $\left(2.64^{* * *}\right)$ & $\left(3.54^{* * *}\right)$ & $(-0.78)$ & $(-1.06)$ \\
\hline \multirow[t]{2}{*}{ Long/Short Debt } & 0.808 & 3.099 & -0.797 & -41.334 \\
\hline & $(2.99 * * *)$ & $(1.14)$ & $(-1.07)$ & $(-2.59 * *)$ \\
\hline \multirow{2}{*}{ Debt Arbitrage } & 0.628 & 1.007 & -1.051 & -26.667 \\
\hline & $\left(2.78^{* * *}\right)$ & $(0.44)$ & $(-1.69 *)$ & $(-2.00 * *)$ \\
\hline \multirow{3}{*}{ Fund of Fund Debt } & 0.568 & 6.433 & -1.150 & -24.102 \\
\hline & $(1.84 *)$ & $(2.07 * *)$ & $(-1.36)$ & $(-1.32)$ \\
\hline & \multicolumn{4}{|c|}{ Panel B: LFI7-10Y } \\
\hline \multirow[t]{2}{*}{ Long-Only Debt } & 0.628 & 10.408 & -0.503 & -19.094 \\
\hline & $(2.87 * * *)$ & $(3.60 * * *)$ & $(-0.63)$ & $(-1.14)$ \\
\hline \multirow[t]{2}{*}{ Long/Short Debt } & 0.636 & 3.234 & -0.686 & -41.100 \\
\hline & $\left(3.12^{* * *}\right)$ & $(1.20)$ & $(-0.92)$ & $(-2.63 * * *)$ \\
\hline \multirow[t]{2}{*}{ Debt Arbitrage } & 0.521 & 1.025 & -0.947 & -27.735 \\
\hline & $(3.07 * * *)$ & $(0.46)$ & $(-1.53)$ & $\left(-2.14^{* *}\right)$ \\
\hline \multirow[t]{3}{*}{ Fund of Fund Debt } & 0.485 & 6.401 & -1.047 & -25.740 \\
\hline & $(2.09 * *)$ & $(2.08 * *)$ & $(-1.23)$ & $(-1.45)$ \\
\hline & \multicolumn{4}{|c|}{ Panel C: LFI5-10Y } \\
\hline \multirow[t]{2}{*}{ Long-Only Debt } & 0.6350 & 11.000 & -0.789 & -22.321 \\
\hline & $\left(2.56^{* *}\right)$ & $(3.82 * * *)$ & $(-0.99)$ & $(-1.21)$ \\
\hline \multirow[t]{2}{*}{ Long/Short Debt } & 0.638 & 3.848 & -0.977 & -44.055 \\
\hline & $\left(2.75^{* * *}\right)$ & (1.43) & $(-1.31)$ & $\left(-2.55^{* *}\right)$ \\
\hline \multirow[t]{2}{*}{ Debt Arbitrage } & 0.470 & 1.652 & -1.195 & -27.433 \\
\hline & $\left(2.41^{* *}\right)$ & $(0.73)$ & $(-1.92 *)$ & $(-1.89 *)$ \\
\hline \multirow[t]{2}{*}{ Fund of Fund Debt } & 0.439 & 6.982 & -1.278 & -25.548 \\
\hline & $\left(1.66^{*}\right)$ & $(2.28 * *)$ & $(-1.51)$ & $(-1.30)$ \\
\hline
\end{tabular}


Table 8

Bootstrap estimates of the joint liquidity timing coefficients

This table summarizes the bootstrap analysis results for cross-sectional individual hedge funds. The number of bootstrap simulations for each hedge fund is 10,000 . The coefficient $\bar{\Sigma}$ measures fixed income market liquidity timing ability and 3 measures equity market liquidity timing ability. The measure of equity market liquidity Pastor-Stambaugh is calculated based on that of Pastor and Stambaugh (2003). The measure of fixed income market liquidity LFI10-15Y is calculated as the difference between the excess rate of the BBB rated BofA Merrill Lynch US Corporate bonds for 10-15 years and the 10-year CDX credit spread. The measure of fixed income market liquidity LFI7-10Y is calculated as the difference between the excess rate of the BBB rated BofA Merrill Lynch US Corporate bonds for seven to 10 years and the 10-year CDX credit spread. The measure of fixed income market liquidity LFI5-10Y is calculated as the difference between the excess rate of the BBB rated BofA Merrill Lynch US Corporate bonds for five to 10 years and the five-year CDX credit spread. The numbers in parentheses are $p$ values. The superscripts * and ** indicate that the correlation is significantly different from zero at the $10 \%$ and $5 \%$, levels, respectively.

\begin{tabular}{lcccccc}
\hline & \multicolumn{2}{c}{ LFI10-15Y } & \multicolumn{2}{c}{ LFI7-10Y } & \multicolumn{2}{c}{ LFI5-10Y } \\
& $\Sigma^{\dagger}$ & उ & $\Sigma^{-}$ & उ & $\Sigma^{-}$ & उ \\
\hline \multirow{3}{*}{ Long-Only Debt } & 0.617 & 10.544 & 0.493 & 10.623 & 0.477 & 11.113 \\
& $\left(0.017^{* *}\right)$ & $\left(0.031^{* *}\right)$ & $\left(0.009^{* *}\right)$ & $\left(0.025^{* *}\right)$ & $\left(0.029^{* *}\right)$ & $\left(0.023^{* *}\right)$ \\
Long/Short Debt & 0.366 & 3.881 & 0.294 & 3.920 & 0.250 & 4.329 \\
& $\left(0.081^{*}\right)$ & $(0.191)$ & $\left(0.055^{* *}\right)$ & $(0.170)$ & $(0.158)$ & $(0.181)$ \\
Debt Arbitrage & 0.433 & 1.194 & 0.354 & 1.214 & 0.304 & 1.692 \\
& $\left(0.033^{* *}\right)$ & $(0.638)$ & $\left(0.012^{* *}\right)$ & $(0.605)$ & $\left(0.088^{*}\right)$ & $(0.540)$ \\
Fund of Fund Debt & 0.425 & 6.483 & 0.353 & 6.482 & 0.307 & 6.946 \\
& $(0.159)$ & $(0.151)$ & $(0.107)$ & $(0.127)$ & $(0.227)$ & $(0.142)$ \\
\hline
\end{tabular}

